\title{
Monitoring the Banggai Cardinalfish, an Endangered Restricted Range Endemic Species
}

\author{
Abigail Moore, ${ }^{1 *}$ Samliok Ndobe ${ }^{2}$ and Muhammad Zamrud ${ }^{3}$ \\ ${ }^{1}$ Fisheries and Marine Science Institute, Palu, Indonesia \\ ${ }^{2}$ Aquaculture Study Program, Tadulako University, Palu, Indonesia \\ ${ }^{3}$ Banggai Fish Quarantine Office, Indonesia
}

\begin{abstract}
Abstrak
Di lingkungan laut hanya sedikit biota yang bersifat endemik. Salah satu yang menarik perhatian adalah Banggai cardinalfish (Pterapogon kauderni, Koumans 1933), sering disingkat BCF, adalah jenis yang berasoisasi dengan ekosistem terumbu karang, endemik di perairan dangkal (kedalaman 0-5m) di sekitar Kepulauan Banggai, Indonesia. Sama halnya dengan kebanyakan wilayah Coral Triangle (Segitiga Karang), perairan pesisir tersebut mengalami tekanan antropogenik yang berat dan beragam. $\underline{P}$. kauderni yang diperdagangan sebagai ikan hias, dimasukkan dalam kategori "Endangered" (terancam punah) pada IUCN Red-List dengan permanfaatan berlebih dan degradasi habitat sebagai ancaman utama. Tahun 2007 usulan untuk didaftarkan pada Lampiran II CITES tidak berhasil, kemudian suatu Rencana Aksi/Action Plan (RA-BCF/BCF-AP) tersusun dan pelestarian BCF menjadi salah satu sasaran Indonesian Coral Triangle Initiative National Plan of Action (CTI-NPOA). Monitoring umumnya dipandang sebagai bagian inti suatu sistem pengelolaan yang efektif. Dalam RA-BCF diharapkan agar monitoring biofisik maupun sosio-ekonomi terhadap perdagangan, populasi dan habitat akan mendukung perkembangan perikanan ikan hias bersifat berkelanjutan sekaligus mewujudkan kelestarian Banggai cardinalfish. Tinjauan terhadap sistem-sistem monitoring yang terbentuk, aktivitas yang terlaksana serta data yang diperoleh menunjukkan beberapa kecenderungan, termasuk peningkatan nyata dalam tingkat ketaatan terhadap aturan karantina yang berlaku, dan perubahan positif lainnya dalam pola pemanfaatan $\underline{P}$. kauderni. Data tersebut bersama dengan hasil penelitian terbaru juga menunjukkan pentingnya adanya perhatian khusus terhadap pelestarian mikrohabitat kunci berupa bulu babi dan anemone laut yang semakin terancam oleh pemanfaatan berlebih. Sistem-sistem monitoring dievaluasi untuk menghasilkan beberapa saran pengembangan aktivitas monitoring agar cakupannya lebih luas dan hasilnya lebih berguna.
\end{abstract}

Kata Kunci: Pterapogon kauderni, Monitoring, Spesies Endemik, Perdagangan Ikan Hias, Pengelolaan Lestari

\begin{abstract}
In the marine realm restricted range endemic species are rare. One such species which has attracted much attention is the Banggai cardinalfish (Pterapogon kauderni, Koumans 1933), often referred to as $\mathrm{BCF}$, a coral reef associated fish endemic to shallow waters $(0-5 \mathrm{~m})$ around the Banggai Archipelago, Indonesia. As in most of the Coral Triangle, these coastal waters are under heavy pressure from a variety of anthropogenic impacts. Traded as a marine ornamental, the IUCN Red-List places $P$. kauderni in the "Endangered" category with overexploitation and habitat degradation as the major threats. After the (unsuccessful) proposal for listing under CITES Appendix II in 2007, a national action plan (BCFAP) was developed and BCF conservation included in the Indonesian Coral Triangle Initiative National Plan of Action (CTI-NPOA). Monitoring is widely accepted as an integral part of effective management. The BCF-AP calls for biophysical and socio-economic monitoring of the Banggai cardinalfish trade, population and habitat to support the development of a sustainable ornamental fishery and ensure the conservation of the Banggai cardinalfish. Monitoring systems developed, activities undertaken and data produced are reviewed. Trends revealed by the data include a marked increase in compliance with current fish quarantine regulations, and other improvements in $P$. kauderni use patterns. Together with recent research, the data also reveal the need for an especial focus on key micro-habitat, Diadema urchins and sea anemones, which are under pressure from increasingly intensive harvesting. Monitoring systems are evaluated and suggestions for improving the usefulness and scope of monitoring activities are presented.
\end{abstract}

Key words: Pterapogon kauderni, Monitoring,Endemic species, Marine ornamental trade, Conservation Management

*Corresponding Authors: abigail2105@yahoo.com 


\section{INTRODUCTION}

In the freshwater aquatic environment there are many species of fish (Pisces) limited to a single watershed or a part thereof, however in the marine realm restricted range endemic fish species are relatively rare. One reason for this is that the majority of marine fish, including many benthic species of a sedentary habit, have a pelagic dispersal phase, usually as eggs and/or larvae. Some marine fishes however do not have such a phase. For example the Banggai cardinalfish (Pterapogon kauderni, Koumans 1933) is a paternal mouthbrooder with direct development, whose fully-formed juveniles settle immediately into the surrounding substrate on release from the male parent's buccal pouch (Vagelli, 2005), therefore lacking pelagic dispersal of eggs or larvae. After settlement, P. kauderni exhibits high site fidelity (Kolm et al., 2005) despite an ontogenetic shift in microhabitat within a given site (Vagelli, 2004). Genetic research indicates that dispersal at the adult stage is minimal (Vagelli et al., 2009). With these life history traits it is not surprising that $P$. kauderni has a very restricted range for a marine fish. This small Apogonid with a maximum standard length (SL) of around $6.5 \mathrm{~cm}$ is endemic to the shallow waters (0-5m, manly $0.5-3 \mathrm{~m}$ depth) around the Banggai Archipelago and a few nearby islands in Indonesia (Vagelli, 2005).

The Banggai cardinalfish is generally considered as a coral reef associated fish, and observed habitat includes reef flats, sea grass meadows and coraldominated areas near the reef crest and/ or upper slope where sufficiently shallow and protected. Large populations can be found in sheltered bays and lagoons and $P$. kauderni have been seen among mangrove roots in some sites (Vagelli, 2005; Ndobe et al., 2005). As in much of the Coral Triangle (Hoegh-Guldberg et al., 2009), the shallow coastal waters of the Banggai Archipelago are under heavy and generally increasing pressure from a variety of direct and indirect anthropogenic impacts, mostly due to the growing human population and changes due to modern lifestyles (Allen and McKenna, 2001; Ndobe et al., 2005; Moore and Ndobe, 2009).
Generally associated with sea urchins, a fact which earned the fish it's local name in the Bajo language (bebese tayung, meaning little sea urchin fish), sea anemones are a particularly important microhabitat for the survival of newly-released recruits and small juveniles, often shared with clown fish, and adult fish tend to dominate in hard coral microhabitat, though this is limited to coral life-forms which offer plenty of refuges, especially branching and foliose forms (Ndobe et al., 2008). There is increasing evidence that these three microhabitats (sea urchins, sea anemones and complex hard coral life-forms) are all important to maintain $P$. kauderni populations, especially sea anemones and sea urchins (Ndobe et al., 2010a\&b).

The Banggai cardinalfish, often referred to using the abbreviation BCF, has been traded as a marine ornamental fish since the 1980's and in large numbers since the 1990's (Lunn and Moreau, 2004; Ndobe et al., 2005) and there has been much international attention to the fate of this attractive endemic fish (e.g. Bruins et al., 2004). The IUCN Red-List places $P$. kauderni in the "Endangered" category (Allen and Donaldson, 2007). Overexploitation is given as the major threat, with habitat degradation also being mentioned.

A proposal by the USA for listing $P$. kauderni under CITES (Convention on the International Trade in Endangered Species of Wild Flora and fauna) Appendix II in 2007 was withdrawn at the $14^{\text {th }}$ Conference of the Parties (CITES, 2007a\&b) and Indonesia made a commitment to $P$. kauderni conservation with a sustainable use approach (Indrawan and Suseno, 2008; Moore and Ndobe, 2007a). A national multi-stakeholder multi-year (2007-2012) Banggai cardinalfish action plan (BCF-AP) was developed at a workshop in August 2007 with a focus on three aspects: Conservation, Trade and Management.

Monitoring is widely accepted as an integral part of effective adaptive management. Effective monitoring requires reliable baseline data, followed by periodic data collection using standard or at the very least compatible methods. Analysis of these data should enable changes and trends to be 
identified, though often additional research may be necessary to establish cause and effect relationships. The BCF-AP calls for biophysical and socio-economic monitoring of the Banggai cardinalfish trade, population and habitat to support the development of a sustainable ornamental fishery and ensure the conservation of the Banggai cardinalfish. Baseline data is available for many aspects of the Banggai cardinalfish population, habitat and trade, and monitoring has been carried out by a number of organisations and individuals. However as yet there is no integrated or comprehensive monitoring system, and few types of data have been or are being collected on a regular, long-term basis.

This paper aims to provide an overview and evaluation of the baseline survey and monitoring activities relevant to sustainable management of the Banggai cardinalfish. These include monitoring of populations, habitat and microhabitat, the fishery and trade, and developments in organisational and management initiatives

\section{METHODS}

Activities included were identified from literature searches as well as personal experience, including recent (unpublished) data collected by the authors. The activities undertaken and data produced were briefly reviewed in terms of scope and output. Trends revealed by the data and management implications were identified. Monitoring activities were evaluated in order to provide suggestions for improving the usefulness of data available for management, and establishing an effective long-term monitoring system to support the commitment made by Indonesia of conserving the Banggai cardinalfish through a sustainable use approach.

\section{RESULTS}

Baseline survey and monitoring activities have been undertaken by a number of organisations and individual researchers, including both biophysical monitoring of the $P$. kauderni population and habitat and socio-economic monitoring of the Banggai cardinalfish trade. In addition there have been a number of studies and research activities which do not fall into these categories but provide valuable additional information, much of which is useful for the evaluation of monitoring results. The main monitoring activities identified are described briefly in Table 1, showing that many data and much information have been collected but that there is no long-term continuous dataset as yet.

Some of the monitoring activities only began recently (e.g. specific $P$. kauderni records kept by the Fish Quarantine). Others now appear to have ceased, e.g. the monitoring by local enumerators from the District Marine and Fisheries Service (MFS) and fishing communities backed by the Ministry for Marine Affaires and Fisheries (MMAF) Marine and Fisheries Research Agency (BRKP). Some have been undertaken on an irregular basis, often depending on the current availability of financial support, e.g. activities by local, national and international NGOs and local academic institutions. Support has been provided by the Sea Partnership Programme (Program Mitra Bahari), the Indonesian Directorate for Higher Education (DIKTI), the Central Sulawesi Provincial Government, the PADI Foundation, and the European Community Poverty Reduction Effectiveness Programme in collaboration with the Network of Aquaculture Centres in Asia (NACA) and the Support to Regional Aquatic Resources Management (STREAM) Hub at the Directorate General for Aquaculture (DGA).

Some research and monitoring activities by foreign researchers were undertaken without proper permits and therefore technically at least illegal. Unfortunately most data and information collected were published internationally but not socialised or made available/accessible to local and national stakeholders until socialisation of the 2004/2005 case study by Yayasan Palu Hijau (YPH) at District, Provincial and National levels (Ndobe et al., 2005). This accounts for the time lag between international concern (e.g. Allen, 2000) and local concern and conservation actions (e.g. Ndobe et al., 2006a\&b). 
Table 1. Overview of known baseline survey and monitoring activities

\begin{tabular}{|c|c|c|}
\hline $\begin{array}{c}\text { Organisation(s) })^{*} \text { and data } \\
\text { source(s) }\end{array}$ & Type of Monitoring & $\begin{array}{l}\text { Time Frame and } \\
\text { Scope or Location }\end{array}$ \\
\hline $\begin{array}{l}\text { Fish Quarantine (Official } \\
\text { records) }\end{array}$ & $\begin{array}{l}\text { Records of fish leaving the area } \\
\text { Specific BCF/ornamental fish } \\
\text { records }\end{array}$ & $\begin{array}{l}\text { Ongoing } \\
2009 \text { - present (Banggai Office) }\end{array}$ \\
\hline $\begin{array}{l}\text { MMAF (BRKP) \& local MFS } \\
\text { (Enumerator reports) }\end{array}$ & $\begin{array}{l}\text { Fishery catch and rejects } \\
\text { Partly participatory }\end{array}$ & $\begin{array}{l}\text { 2008: Bone Baru, Toropot, } \\
\text { Mbuang-Mbuang } \\
\text { 2009: Bone Baru, Toropot, } \\
\text { Bone Bone }\end{array}$ \\
\hline $\begin{array}{l}\text { Local NGO YPH } \\
\text { (Ndobe et al., 2005) }\end{array}$ & $\begin{array}{l}\text { Population and Habitat } \\
\text { Fishery and Trade } \\
\text { (some monitoring based on Lunn \& } \\
\text { Moreau } 2001 \text { baseline) }\end{array}$ & $\begin{array}{l}\text { Baseline data } 2004 \text { (Banggai } \\
\text { Island, Bokan Kepulauan, } \\
\text { Liang) }\end{array}$ \\
\hline $\begin{array}{l}\text { Local NGO LP3L Talinti/Sea } \\
\text { Partnership Programme } \\
\text { (LP3L Talinti, 2006) }\end{array}$ & $\begin{array}{l}\text { Monitoring based on } 2004 \text { baseline } \\
\text { Population and Habitat } \\
\text { Fishery and Trade } \\
\text { In connection with provincial } \\
\text { government program }\end{array}$ & $\begin{array}{l}\text { Monitoring } 2006 \\
\text { (Banggai Island) } \\
\text { Monitoring } 2009 \\
\text { (Banggai Island, mainly Bone } \\
\text { Baru) }\end{array}$ \\
\hline $\begin{array}{l}\text { Academic } \\
\text { (STPL, UNTAD) } \\
\text { Scientific papers and official } \\
\text { reports }\end{array}$ & $\begin{array}{l}\text { Population, Habitat, Trade } \\
\text { Associated with research and/or } \\
\text { provincial government programs } \\
\text { Monitoring based on } 2004 \text { baseline } \\
\text { and LP3I Talinti (2006) }\end{array}$ & $\begin{array}{l}2007 \text { (Banggai) } \\
2010 \text { (Bone Baru) } \\
2011 \text { (Banggai) }\end{array}$ \\
\hline $\begin{array}{l}\text { National NGO LINI } \\
\text { LINI reports and presentations }\end{array}$ & $\begin{array}{l}\text { Trade - local and to some extent } \\
\text { international trade (MAC links) } \\
\text { Habitat \& population } \\
\text { Mostly participatory }\end{array}$ & $\begin{array}{l}\text { 2008-present (2011) } \\
\text { Bone Baru (some export) } \\
\text { Fishing Grounds and some } \\
\text { other sites }\end{array}$ \\
\hline $\begin{array}{l}\text { Vagelli } \\
\text { (Vagelli \& Erdmann, 2002; } \\
\text { Vagelli, } 2005 \text { \& 2008; CITES } \\
\text { proposal documents) }\end{array}$ & $\begin{array}{l}\text { Population baseline } \\
\text { Monitoring of population density at } \\
\text { some sites } \\
\text { Possible further monitoring? }\end{array}$ & $\begin{array}{l}\text { 2001, 2002, } 2004 \\
\text { 2002, } 2004 \text { (many sites) } \\
\text { (more recent visits?) }\end{array}$ \\
\hline $\begin{array}{l}\text { Lunn and Moreau (Lunn \& } \\
\text { Moreau } 2001 \& 2004)\end{array}$ & $\begin{array}{l}\text { Trade baseline data } \\
\text { (used as baseline by several } \\
\text { subsequent researchers/teams) }\end{array}$ & $2000 / 2001$ \\
\hline $\begin{array}{l}\text { Acroporis } \\
\text { (French NGO) } \\
\text { http://www.acroporis.fr }\end{array}$ & $\begin{array}{l}\text { Trade through Tumbak and involving } \\
\text { Tumbak buyers }\end{array}$ & $2006-2008$ \\
\hline
\end{tabular}

\footnotetext{
* Abbreviations: NGO = Non-Governmental Organisation; MMAF = Ministry for Marine Affaires and Fisheries; MFS = District Marine and Fisheries Service; BRKP = Marine and Fisheries Research Agency of the MMAF; YPH = Yayasan Palu Hijau; LINI $=$ The Indonesian Nature Foundation; STPL = Sekolah Tinggi Perikanan dan Kelautan (Fisheries and Marine Science Institute); UNTAD = Tadulako University
} 


\section{BCF-AP Implementation and Organisational Aspects}

Annual stakeholder meetings have been held since the 2007 meeting at which the Banggai Cardinalfish Action Plan (BCFAP) was produced: in Palu (2008), Luwuk (2009), Banggai and Jakarta (2010) and Bone Baru on Banggai Island (2011). Though the initiating agency and the main focus of each event has been different, all have provided an opportunity to share data and information, review progress, and adjust short-term goals. Some information on the early stages of implementation has been presented at national and international events (e.g. Ndobe and Moore, 2009; Moore and Ndobe, 2010a\&b; Ndobe et al. 2010a\&b).

P. kaudernimanagement and conservation has consistently been included in sectoral plans at national and local levels, and in particular was included in the Indonesian Coral Triangle Initiative National Plan of Action (CTI-NPOA) in 2009 (Jompa, 2009). Though this action plan has not yet entered the implementation phase (Jompa, pers. com, 2011), this is an opportunity for international as well as increased national support in the future.

A key component of the BCF-AP, a multi-stakeholder umbrella body for $P$. kauderni management, was achieved in 2007 through the establishment of The Banggai Cardinalfish Centre (BCFC) by Decree of the District Head SK Bupati No 168/2007. A purpose-built BCFC office was constructed in Bone Baru in 2009, but by the meeting in September 2011 still had no electricity, minimal fittings and no office or other operational supplies. Since its establishment, the BCFC has had no operational budget and activities have been carried out on a voluntary basis or with support from specific projects (e.g. the training events organised by the NGO LINI).

Supporting legislation is seen as vital to the long-term achievement of the BCFAP goals, and has been in progress since 2008. The main obstacle has been the lack of intermediary level legislation under the Constitutional Law No 31/2004 on Fisheries and Law PP No.60/2007 on the Conservation of Fisheries Resources as a legal basis for species-level legislation. At the 2011 meeting in Bone Baru the outline draft for a Ministerial Decree was agreed, with a target of promulgation before the end of 2011. The scope of this proposed Decree is more limited than the comprehensive Fisheries Management Plan (RPP-BCF) originally envisaged, but would provide a legal basis for many current and proposed management actions, for example size limits and quotas. Provisional quotas were agreed at a meeting in Banggai in 2010, and provisional size limits $(2.5-4 \mathrm{~cm} \mathrm{SL})$ were set at the 2011 Bone Baru meeting.

Significant challenge as this island comprises 4 Sub-Districts with relatively high human population density as well as the main Banggai cardinalfish fishing grounds. Two village level community marine protected areas have been proposed (Bone Baru and Tinakin Laut), and in Bone Baru there have been practical implementation measures though as yet no legal basis. A decree by the village head has been under discussion for at several years now. In 2010 the BCF Lestari fishermen's group and other local community representatives expressed a desire for independent facilitation to help the villagers from a technical (legal) viewpoint and to reconcile the (largely minor) differences of opinion within the community (Saputra, 2010).

\section{Fishing Grounds and Fishing Villages}

The extent of known $P$. kauderni fishing grounds in 2001 (Lunn and Moreau, 2004), 2004 (Ndobe et al., 2005) and 2006 (LP3L Talinti, 2006) included most of the known distribution of the species, as shown in Fig. 1A. In 2008 and 2009 there was some indication of a reduction in fishing ground extent and by 2011 there were strong indications based on information from a number of key informants that the areas actively fished have substantially reduced as shown in Fig. 1B. There have also been substantial changes in the villages engaged in P. kauderni collection (fishing villages), as can be seen from the data in Table 2 . 

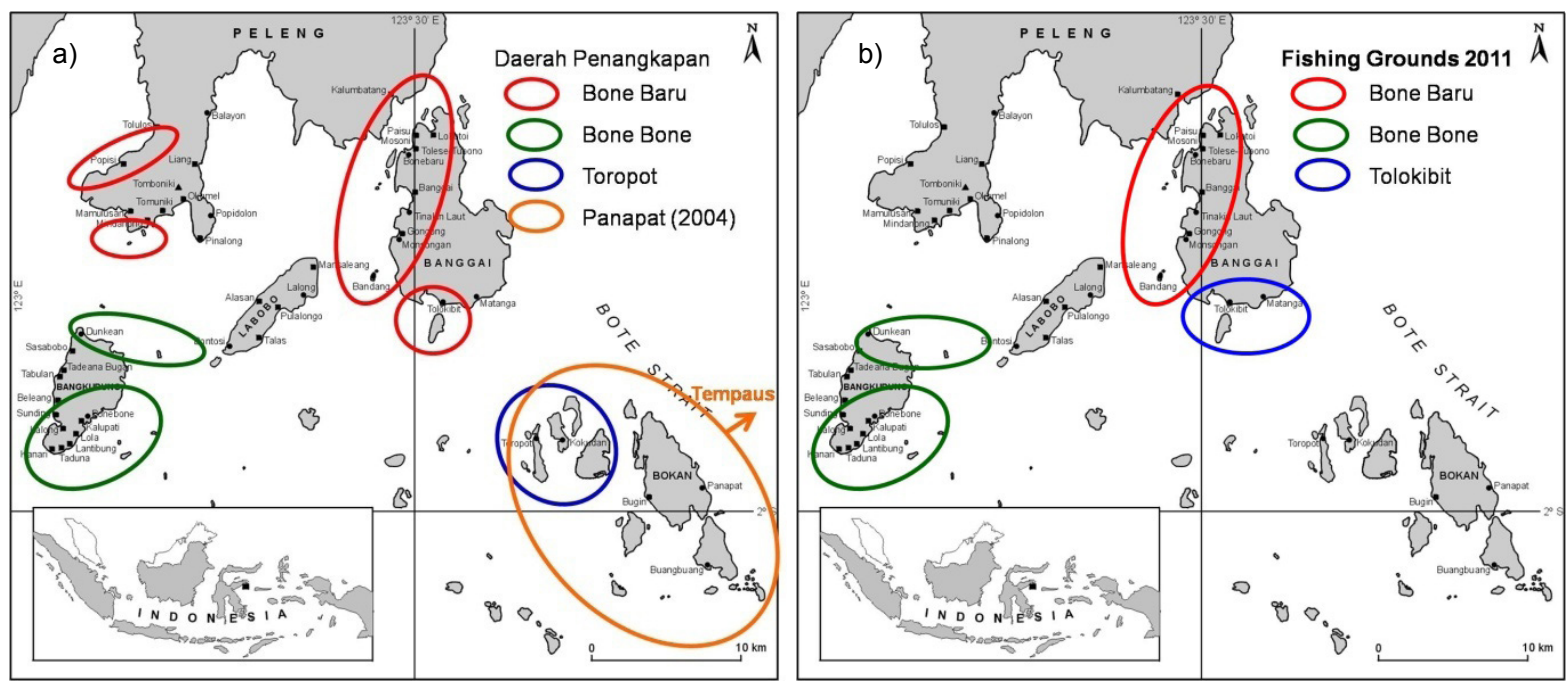

Source: Ndobe et al. (2005) and primary data, 2011

Fig. 1. Known P. kauderni fishing grounds in 2004 (A) and 2011 (B)

Table 2. Pterapogon kauderni Fishing Villages

\begin{tabular}{|c|c|c|c|c|c|c|}
\hline \multirow{2}{*}{$\begin{array}{l}\text { Island or } \\
\text { Sub-District }\end{array}$} & \multirow{2}{*}{ Village } & \multicolumn{5}{|c|}{ Status ( $\mathrm{A}=$ Active; $\mathrm{N}=$ Not Active; $\mathrm{P}=$ Possibly Active) } \\
\hline & & $2001 / 2002$ & 2004 & 2006 & 2008/9 & 2011 \\
\hline \multirow{5}{*}{ Banggai } & Bone Baru & A & A & A & A & A \\
\hline & Tinakin Laut & A & A & $\mathrm{N}$ & N & $\mathrm{N}$ \\
\hline & Monsongan & A & A & $\mathrm{N}$ & N & $\mathrm{N}$ \\
\hline & Tolokibit & A & A & $\mathrm{N}$ & $\mathrm{N}$ & A \\
\hline & Matanga & A & no data & $\mathrm{N}$ & N & $\mathrm{N}$ \\
\hline \multirow{4}{*}{$\begin{array}{l}\text { Bokan } \\
\text { Kepulauan }\end{array}$} & Toropot & A & A & A & A & $\mathrm{N}$ \\
\hline & Panapat & A & A & $P$ & $P$ & $N$ \\
\hline & Kokudang & A & $N$ & $\mathrm{~N}$ & $N$ & $N$ \\
\hline & Mbuang-Mbuang & A & $N$ & $\mathrm{~N}$ & $N$ & $N$ \\
\hline \multirow{2}{*}{ Bangkurung } & Bone Bone & A & A & A & A & A \\
\hline & Dunkean & A & $N$ & N & $N$ & $\mathrm{~N}$ \\
\hline Other & $\begin{array}{l}4 \text { villages with } \\
\text { very low volume }\end{array}$ & A & $N$ & $\mathrm{~N}$ & $N$ & $\mathrm{~N}$ \\
\hline
\end{tabular}

Sources : Lunn and Moreau (2001); Ndobe et al. (2005); LP3L Talinti (2006); Latupono (2008 \& 2009); Saputra (2010); unpublished data (2011) 
In 2000/2001 there were around 12 villages engaged in P. kauderni collection, and an increasing trend in the number of fishers and fishing villages over the period 1998-2001 was reported (Lunn and Moreau, 2001). By 2004 several of these villages were no longer active or very rarely collecting and trading, leaving 7 (possibly 8 ) villages still involved in collecting $P$. kauderni (Ndobe et al., 2005). In 2006, Bone Baru was the only village still active on Banggai Island (LP3L Talinti, 2006) and overall the number of trading villages had been reduced to four villages, as shown in Fig. 1A. However, there are now two villages actively fishing on Banggai

Island, with fishers in Tolokibit (one of the villages active in 2001 and 2004) now once again collecting fish which are traded on a regular basis via Kendari, sometimes together with some fish collected by Bone Bone fishermen. Conversely Toropot, still active in the $P$. kauderni fishery and trade up to 2010 (Saputra, 2010), is not currently active according to information from the 2011 stakeholder meeting in Bone Baru.

The overall trend is of a reduction in the number of people fishing and the extent of fishing grounds. It can be seen that there are only two villages which have remained consistently active, Bone Baru on Banggai Island and Bone Bone on Bangkurung Island. Based on key informant interviews, the main reason for villages such as Toropot, Tolokibit and Panapat to become active or to cease activity is the presence or absence of visiting buyers. Another major change is the tendency for fishers to remain closer to their bases, due to increased overhead costs. This is one reason for the reduction in extent of the Bone Baru fishing grounds. There is some anecdotal evidence that the reduction in visitation by fishers and buyers from Bali and Java, in particular the Balinese traders who worked in partnership with Panapat villagers, is also due to the costs of roving fishing. Despite minimal surveillance and enforcement, it is likely that the increasingly negative attitude of local people to those perceived as "fish thieves" may also have played a role in the observed and reported decline of roving $P$. kauderni fisher/buyers, most if not all of whom would have been operating illegally (without valid permits and other documents or indeed without permits at all), and/or involved in the use of poisons to catch other (more valuable and less easy to catch) ornamental species.

This reduction in fisher numbers has been coupled with an increase in professionalism. In 2001 (Lunn and Moreau, 2001) there were no fishermen's groups with legal status, and this was still the case in 2006 (LP3L Talinti, 2006). In Bone Baru the ornamental fishermen's group, called Kelompok BCF Lestari, is now legally established, a process facilitated in 2009 by the local NGO LP3L Talinti and the BCFC with support from the Provincial Marine and Fisheries Service BCF-AP implementation program. The $P$. kauderni fishing patterns in this village began to be more sustainable after socialisation in 2005 and 2006, for example brooding males were no longer captured. Since then there have been further technical improvements in capture methods and post-harvest care, in particular due to an ornamental fishery training workshop in 2009 which included representatives from several fishing villages and related institutions, and subsequent guidance from a community facilitator based in Bone Baru, both provided by the NGO LINI in partnership with the BCFC, supported by the PADI Foundation. The group members in general are keen to manage their resources wisely, indeed several have become active in local conservation efforts, a trend noticeable since community MPA and coastal resources management training for stakeholders including Bone Baru and Tinakin Laut villagers in 2006 under the Sea Partnership Program.

There is still a need to extend the improvements in Bone Baru to other $P$. kauderni fishery and trade centres. This was apparent from discussions with the fishers and traders involved in the TolokibitKendari trade route in 2011 as well as from the annual stakeholder meetings. 


\section{Trade}

In the year from March 2000 to April 2001 , the total volume of $P$. kauderni traded from the Banggai Islands was estimated at between 700,000-1.4 million fish/year based on data collected by Lunn and Moreau (2001 \& 2004). When compared to the estimated total population of 2.4 million (Vagelli and Erdmann, 2002), it is not surprising that there was serious concern for the future of this species (e.g. Bruins et al., 2004).

Local survey and monitoring activities estimated the volume over the period 20042006 at around 600,000-700,000 fish/year, close to the lower limit of the estimate by Lunn and Moreau and also to the estimate given in Vagelli and Erdmann (2002). These data were based on information supplied by fishermen and traders in the Banggai Islands. In 2008, the Marine Aquarium Council (MAC) and LINI estimated the total international demand at around 450,000 fish/year, a Fig substantially lower than the number of fish collected. The difference is thought to be due to high levels of mortality and rejects (e.g. fish with damaged fins) in the market chain, as well as to the practice of collecting and buying speculatively rather than on demand (e.g. by intermediary buyers from Tumbak in North Sulawesi). The release of unsold fish, including rejects, has been one reason introduced populations have become established.

There are no reported cases of natural $P$. kauderni population expansion, but introduced populations have been reported in Luwuk (Vagelli and Erdmann, 2002), Palu Bay (Moore and Ndobe, 2007b); Lembeh (Erdmann and Vagelli, 2001); North Bali (Lilley, 2008) and Kendari (personal observation, 2011).

The trade monitoring scheme by the Ministry for Marine Affaires and Fisheries (MMAF); Marine and Fisheries Research Agency (BRKP) with enumerators from the District Marine and Fisheries Service (MFS) and the ornamental fishing community collected data in 2008 and 2009 including numbers of fish caught, mortality and numbers of rejected fish, and fishing grounds by fisherman and village. In each year these data were routinely collected in three villages. In 2008, the villages monitored were Bone Baru, Toropot and Mbuang-Mbuang. However, as in 2004 Mbuang-Mbuang was actually a fishing ground (for Panapat fishers working with Balinese roving collectors), not a $P$. kauderni fishing village (Ndobe et al., 2005), it is not surprising that there were no fish collected in the data for this village. In 2009 the third village was changed to Bone Bone, an active $P$. kauderni fishing village on the Island of Bangkulu or Bangkurung (synonym names). A synopsis of the data is presented in Table 3. While not presenting a complete record of $P$. kauderni trading, these Figs do indicate a reduction in overall trade volume and, importantly, a decrease in mortality which in 2004 was frequently in excess of $10 \%$ (Ndobe et al., 2005). Observation and anecdotal information indicate there may be some under-reporting of rejects (often released near to the fishing villages) and mortality.

Current legislation requires that all fish and fish products must go through Fish Quarantine procedures before crossing internal administrative boundaries as well as leaving the country (export). Fish not going through Fish Quarantine procedures are, de-facto, illegally traded. In 2004, only one $P$. kauderni trader (then operating a route via Luwuk and Palu) had ever followed Fish Quarantine procedures for P.kauderni leaving the Banggai Islands. The Fish Quarantine Service was one of the stakeholders involved in the 2005 socialisation and the 2007 BCF-AP workshop, and is represented in the BCFC. In 2008, a branch office was established in Banggai, on Banggai Island and since 2008 specific records of the legal $P$. kauderni trade have been kept. The data collected are shown in Table 4 and Fig. 2. trade of fish from introduced populations in Indonesia and from captive P. kauderni breeding, mainly in consumer countries. 
Table 3. Synopsis of the "BCF enumerator" data for 2008-2009

\begin{tabular}{cccccc}
\hline Parameter & Year & Bone Baru & Village Toropot & Bone Bone & Total \\
\hline No. BCF caught & 2008 & 162,940 & 73,433 & no data & 236,373 \\
& 2009 & 155,156 & 89,340 & 85,920 & 330,416 \\
Mortality (\%) & 2008 & $2.6 \%$ & $0.7 \%$ & no data & $2.0 \%$ \\
& 2009 & $0.1 \%$ & $0.3 \%$ & $0.8 \%$ & $0.3 \%$ \\
\hline
\end{tabular}

Source: Latupono (2008 \&2009)

Table 4. Fish Quarantine Data 2008-2011 ( BCF legal shipment volume)

\begin{tabular}{lcccc}
\hline Parameter & $\mathbf{2 0 0 8}$ & $\mathbf{2 0 0 9}$ & $\mathbf{2 0 1 0}$ & 2011 (to June) \\
\hline Total volume & 83,200 & 215,950 & 148,800 & 56,900 \\
Average monthly volume & 7,564 & 17,996 & 12,400 & 9,483 \\
Total no of shipments & 42 & 77 & 77 & 58 \\
Average monthly shipments & 4 & 6 & 6 & 10 \\
Average no of fish/shipment & 2,092 & 3,204 & 1,985 & 708 \\
\% of enumerator trade data & $36 \%$ & $66 \%$ & $\mathrm{n} / \mathrm{a}$ & $\mathrm{n} / \mathrm{a}$ \\
\hline
\end{tabular}

Source: Fish Quarantine Records

Trends revealed by trade data include a marked increase in compliance with current fish quarantine regulations, and other improvements in $P$. kauderni use patterns. As all fish going through Fish Quarantine in 2008 and 2009 were from the villages monitored by the enumerators, it can be seen that there was a significant increase legal trade in terms of the number of fish and the percentage of the total trade volume. In 2010 there was a decrease in the numbers of $P$. kauderni traded through Bone Baru, largely due to a policy of linking capture to demand, with exporters ordering fish in line with the demand from overseas importers. This linkage, facilitated by LINI, the Fish Quarantine Service and the BCFC, was made possible by the above-mentioned improvements in handling procedures as well as improvements in transport and communication infrastructure. In particular, the enlargement of Luwuk airport to handle regular domestic flights with air cargo facilities. This enabled the opening of a more direct trade route from Banggai Island to Luwuk by sea, and by air to Jakarta or Denpasar transiting through Makassar.

Another significant change is the price paid per fish. From 2001 to 2006 this remained at around 200-300Rp./fish. In 2008 and 2009, most BCF were sold for 350 $\mathrm{Rp}$./fish. The new trade route and improved quality of fish supplied have enabled Bone Baru fishers at least to increase the price per fish to 500Rp. Eventually, it is estimated that it should be possible to attain a price to fishers of around 1,000 Rp. each, which the fishermen consider would be a good price. The economics of the market chain make much higher pricing unlikely in the foreseeable future (Saputra, 2010).

Collectively, the villages monitored in 2008 and 2009 collected numbers of $P$. kauderni below the estimated global demand. Based on the estimated population of 2.4 million this level of trade is unlikely in itself to cause extinction of the Banggai cardinalfish. It is known that there is some trade of fish from introduced populations in Indonesia and from captive P. kauderni breeding, mainly in consumer countries. 

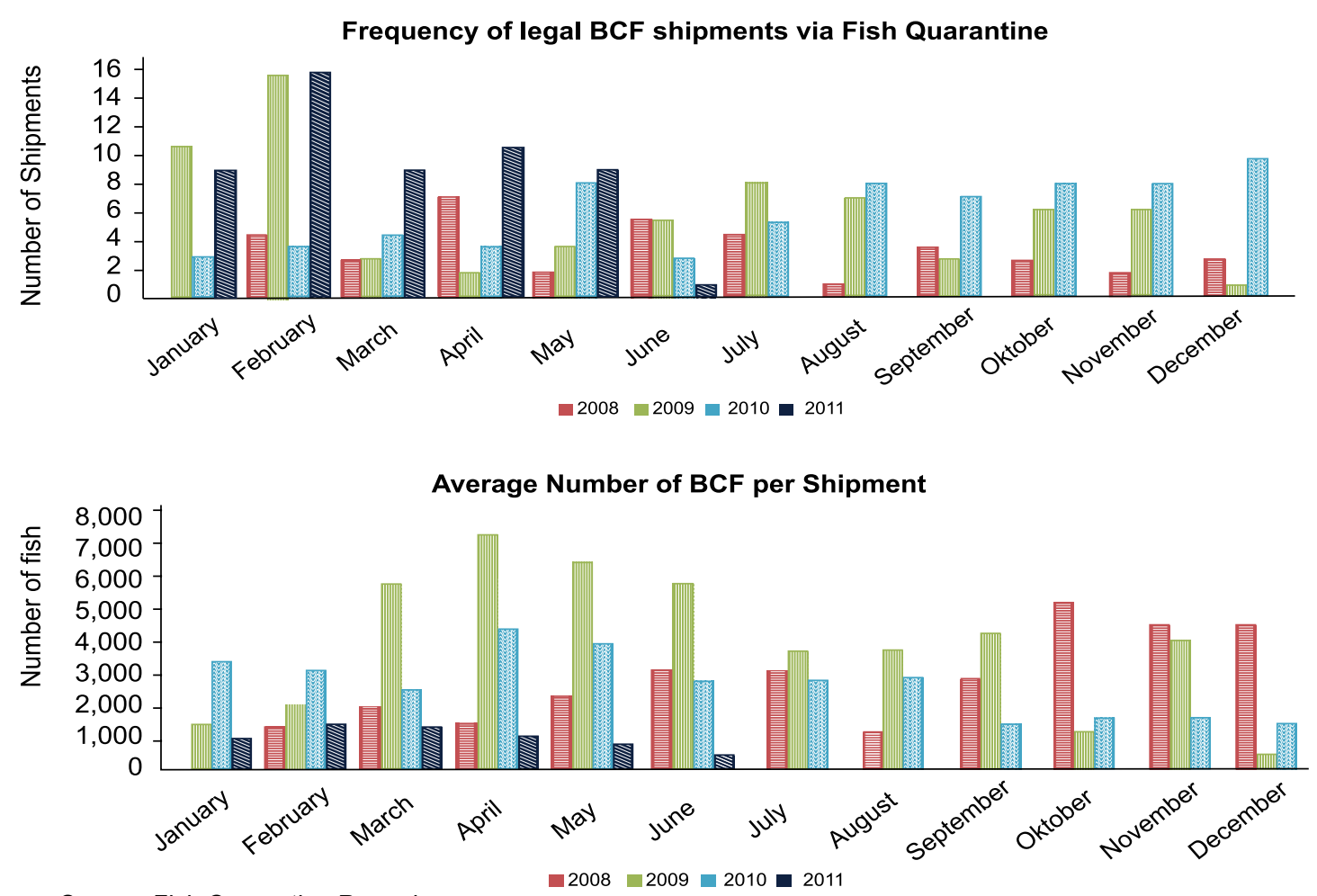

Source: Fish Quarantine Records

Fig. 2. Monthly Fish Quarantine data on P. kauderni shipments

\section{Habitat and Microhabitat}

Survey and monitoring of overall habitat condition has revealed significant degradation from direct and indirect threats (Ndobe, et al., 2005 \& 2008; LP3L Talinti, 2006; Moore and Ndobe, 2009). Direct impacts include coral mining; the gleaning of invertebrates for food and other uses (not perceived as fishing); fishing pressure, sometimes including the use of destructive methods; coastal development projects, including the construction of sea walls (sosay to avoid coastal abrasion), and the construction of public infrastructure (such as the new port at Tinakin Laut); and residential development, including the replacement of traditional homes (constructed of wood, bamboo, and other natural materials) with "permanent" concrete and breeze-block dwellings, a shift strongly supported by government development policy. Public works and private constructions are major drivers of coral and sand mining, despite these practices being theoretically illegal. Indirect impacts from the increasing pressure on land-based resources of these small islands include sedimentation and changes in hydrology and water quality, and occasional population explosions of the coral predator Acanthaster plancii, generally considered as an indication of ecological imbalance.

Key results of $P$. kauderni population survey and monitoring include relationships between fishing pressure and population density as well as population structure. Heavy fishing pressure is correlated with lower population density, but there has been no significant difference found between lightly/moderately fished sites and unfished sites in terms of population density (Kolm and Berglund, 2003; Ndobe et al., 2005; LP3L Talinti, 2006). Monitoring of both the endemic population and Palu Bay introduced population (including published and unpublished data) indicates that all levels of fishing alter population structure with a higher percentage of recruits and smaller juveniles observed at sites recently fished or fished at intervals of up to 3-4 months.

A recent threat to $P$. kaudernipopulations, massive consumption of key microhabitat, was first revealed by survey and monitoring activities in 2007 (Ndobe et al., 2008). A 
drastic population decline occurred at a site in Tinakin Laut village waters after the sea anemones (highly visible in 2004 and 2006) all disappeared. It turned out that the anemones had been collected and eaten. Apparently this has long been a practice of hill farming communities (orang gunung) during drought periods when they have difficulty in obtaining other sources of protein, however in the past the collection would not have been on such a large scale. A similar case of increasing collection and consumption by hill farmers (orang gunung) has been reported from Tolokibit, this time focused on sea urchins. One-off collection of sea anemones also led to a drastic reduction in numbers of recruits and small juveniles at Mamboro in Palu Bay, a site frequently observed since 2006. All large groups of recruits observed in the wild since 2004 by the authors have been sheltered in sea anemone micro-habitat. Recent reduction in sea urchin and sea anemone populations at another site in Palu Bay (from unknown causes) resulted in a situation where almost all fish crowded into the remaining urchins were adults, with no recruits or small juveniles visible, despite large numbers of brooding males (i.e. high reproductive activity), indicating a significant drop in recruit/juvenile survival. Monitoring by LINI and the BCF Lestari fishermen's group in 2010 and 2011 (Artiawan, pers. com., 2011) confirmed key informant information obtained from socioeconomic monitoring in 2009 that intensive harvesting of shallow-water invertebrates including sea anemones, and in particular large-scale consumption of sea urchins, was becoming more wide-spread. This harvesting has caused visible declines in sea anemone and sea urchin populations and is correlated with equally visible (and in some cases measured) reductions in $P$. kauderni populations, both within and at sites outside fishing grounds.

There are very strong indications that although in some cases collection is by hill farmers or other fisher folk, the main reason for the shift in fishing and consumption patterns is related to the development of seaweed farming. Fishers turned seaweed farmers seek protein to feed themselves and their families in the shallow waters around their farms, resulting in intensive harvesting of all edible benthic invertebrates, including the sea anemones and sea urchins which provide key $P$. kauderni micro-habitat.

As yet there has been no structured quantitative or socio-economic research into this phenomenon, however it is already clear that the threat to $P$. kauderni populations is serious and that it will not be easy to find a workable solution. Protected status for the sea anemones (several species) and Diadema sea urchins is highly unlikely to be workable, even if the laws could be put in place. Traditional (Adat) regulation might work in those communities which are still homogenous and recognise a traditional authority (e.g. the traditional King of Banggai, or at present the Regent as the King is under age), however would be unlikely to work well in more heterogeneous communities. Village level regulations would be difficult to set up in a situation where so many villages are involved. Education and awareness building would certainly require very substantial resources, not least in order to identify the drivers and possible effective entry points. Possible media could be the development of materials for the Local Content (Muatan Lokal) in school curricula, or the local radio. However experience shows that even knowledgeable and aware people are often still inclined to harvest resources which are already protected (e.g. giant clams, turtles) let alone legal fisheries resources.

\section{Evaluation}

There are many positive aspects of the monitoring activities to date. Many government and non-government organisations have been involved, and most have shown a high level of commitment. Survey/monitoring activities have identified problems as well as changes (positive and negative) which could well have otherwise gone undetected or been misinterpreted. Data has been used (e.g. during the CITES process, in preparing proposals, planning and implementing programs and initiatives). Strengths and opportunities which can 
be built on include the National Action Plan (BCF-AP) and other policies (e.g. CTI-NPOA) and planned legislation; the existence of an umbrella body (the BCFC) with a legal basis and a dedicated office; and the development of inter-stakeholder communication channels, even though use of these has often been limited.

Weaknesses which need to be addressed include the fact that most monitoring has been and still is irregular (often due to lack of resource), with no overall strategy/plan and there is a lack of coordination between organisations (GO and NGO) in planning, implementation and socialisation of results. There has been no common agreement on methods/protocols, and activities undertaken are not always truly "monitoring" due to shifts in location, method, etc. There are some overlaps and many gaps in scope, temporal and spatial coverage and there is still a lack of some important baseline data (e.g. limited spatial coverage).

\section{Strategy}

Comprehensive and Integrated Monitoring needs coordination. An umbrella organisation exists - the BCFC. A priority should be to empower the BCFC to coordinate as per the original BCF-AP concept, including in the field of monitoring. The BCFC has an office, but no funds, basic supplies or even electricity. The Decree (SK Bupati) appointed the BCFC members in 2007 but is now outdated. As yet there is no constitution (Anggaran Rumah Tangga) and no general (annual) or routine committee meetings have been held. Activities have been opportunistic, largely made possible through the high level of personal commitment of some members. The BCFC should have a proper constitution, including a mechanism for regular revision of the executive committee, and a reliable source of finance sufficient at least to enable the performance of the basic tasks assigned to the Centre.

Monitoring scope, protocols and human resources need to be addressed. This should incorporate existing routine activities (e.g. by the Fish Quarantine Service).
There should be an agreement on a minimum scope of monitoring to support conservation management, including a sustainable fishery and trade and a needs assessment to establish gaps: what is monitored; method/protocols; spatial and temporal scope; human resources; financial resource; logistics; etc. This will enable stakeholders to agree basic protocols, especially for population/habitat monitoring; identify sources of financial/logistic support and seek firm commitments; agree on who is responsible for each basic monitoring component; consider outputs: effective mechanisms for socialisation and input to management.

\section{CONCLUSION AND RECOMMENDATIONS}

There is considerable evidence from monitoring activities to date that the $P$. kauderni fishery and trade in the Banggai Archipelago, once considered the main threat to the survival of this restricted range endemic species, is now a factor promoting conservation of the shallowwater ecosystems of the Banggai Archipelago, in particular through raised awareness among those directly involved and the wider community and the value of the Banggai cardinalfish as a local icon (flagship species). Monitoring to date has shown an increase in compliance with legal requirements, improved organisational structure (fisher group), technical aspects of the fishery and trade and an increase in the price per fish paid to fishers. There has been a decrease in illegal trade, destructive practices (especially the collection of brooding males), and mortality. It can be concluded that although there is a need for ongoing efforts and constant vigilance to maintain and extend the improvements, overall the $P$. kauderni fishery is well on the way to the goal of a sustainable ornamental fishery first set by local stakeholders in 2005 and then the national BCF-AP in 2007.

In a review of marine biodiversity patterns, threats and conservation needs, Gray (1997) stated that "loss of habitat is the most serious threat to marine biodiversity". 
Overall, monitoring results indicate that loss of habitat, especially the key microhabitat organisms (Diadema urchins and sea anemones) which are under pressure from increasingly intensive harvesting, is now the main threat to conservation of the endemic $P$. kauderni population and indeed to the ornamental fishery. This is a recent threat, caused by socio-economic changes, including the expansion of seaweed farming. Since first reported in 2007 there evidence that this phenomenon has rapidly become more widespread and severe though the true extent is not known. It involves many stakeholders who are unaware of the Banggai cardinalfish, the fishery, and related conservation issues. How to protect sea urchins and sea anemones is a major challenge. There is a clear need for further research and monitoring of the situation.

Monitoring to date has played a valuable role in informing stakeholders of the progress of initiatives undertaken, highlighting gaps and revealing new developments which need to be taken into consideration to ensure the long-term conservation of the Banggai cardinalfish. It is clear that there is a need to continue the improvements in the fishery and trade, and to find ways to protect $P$. kauderni habitat, especially the key micro-habitats (sea anemones and sea urchins). Monitoring of both biophysical and socio-economic trends needs to be continued long-term. The only long-term monitoring with a guaranteed funding source is the Fish Quarantine records.

One cost-effective way of developing a long-term integrated monitoring program would bethroughempowermentand capacity building for the BCFC. Local community members, including the fishermen's group members could do much of the routine data collection, a process which has already been begun through the BCF enumerator program and the monitoring initiated by LINI. Other BCFC affiliated organisations such as academic and research institutions could supplement this with less frequent but more detailed monitoring and analysis, all coordinated through the BCFC. Monitoring is not just about the data, but also the socialisation and use of the results. It is particularly important to ensure feedback to local stakeholders. So far this has largely been achieved through annual meetings but in the long term this should also be a major role for the BCFC.

In order for the BCFC to play all these key monitoring-related roles, outlined in the BCF-AP, the Centre needs to be empowered not just in terms of human resources and equipment but also financial resources. Finance could be from routine central and local government allocations and donations from concerned national or international organisations or individuals. Development of eco-tourism would open up new opportunities both for finance and participation in monitoring activities.

Lastbutnotleast, the Banggaicardinalfish is native to a small area of Indonesia, but has already been acknowledged as part of the global heritage. Any constructive ideas for improving the conservation and monitoring of the Banggai cardinalfish and its habitat in general, and in particular for addressing the problem of consumption of key microhabitat (sea anemones and sea urchins), will be most gratefully received.

\section{Acknowledgments}

The authors wish to thank the many individuals and organisations without whom the writing of this paper would not have been possible. Firstly, all the people and organisations who were directly involved in the survey and monitoring activities mentioned and/or provided data and information from academic, local and central government, NGO and community backgrounds, and especially the BBCF Lestari fishermen's group and BCFC members. Secondly, the organising committee of the $2^{\text {nd }}$ Coral Reef Management Symposium on Coral Triangle Area, who accepted the paper for presentation. Last but not least, all who provided financial, in-kind or moral support for the preparation and presentation of this paper, in particular the Fish Quarantine Service in Luwuk and Kendari, colleagues at the Sekolah Tinggi Perikanan dan Kelautan, the Tadulako University Aquaculture Study Program and LP3L Talinti in Palu. 


\section{REFERENCES}

Allen, G.R. 2000. Threatened fishes of the world: Pterapogon kauderni Koumans, 1933 (Apogonidae). Environmental Biology of Fishes 57:142

Allen, G.R. and Donaldson, T.J. 2007. Pterapogon kauderni. In: IUCN 2009. IUCN Red List of Threatened Species. Version 2009.1. (http://www.iucnredlist.org, downloaded 11 July 2009)

Allen, G.R. and McKenna, S.A. (eds.). 2001. A Marine Rapid Assessment of the Togean and Banggai Islands, Sulawesi, Indonesia. RAP Bulletin of Biological Assessment 20. Conservation International, Washington DC, USA.

Bruins, E.B.A., Moreau, M.A., Lunn, K.E., Vagelli, A.A., and Hall, H. 2004. 10 Years after rediscovering the Banggai Cardinalfish. Musée Océanographique, Monaco. Bulletin de I'Institut Océanographique 2004, Vol. 77 No.1446:71-81

CITES. 2007a. COP 14 Prop. XX. Convention on the International Trade in Endangered Species, Fourteenth meeting of the Conference of the Parties, The Hague (Netherlands), 3-15 June 2007, Consideration of Proposals for Amendment of Appendices I and II. Proposal: Inclusion of the Banggai cardinalfish (Pterapogon kauderni, Koumans 1933) in Appendix II of CITES. (http://www. cites.org, downloaded 21 January, 2007)

CITES. 2007b. Summary record of the 10th session of Committee I. E14-Com-I-Rep-10. (http://www.cites.org, downloaded 24 June 2007)

Erdmann, M.V. and Vagelli, A.A. 2001. Banggai Cardinalfish Invade Lembeh Strait. Coral Reefs 20:252-253.

Gray, J.S. 1997. Marine Biodiversity: Patterns, Threats and Conservation Needs. Biodiversity and Conservation 6:153-175

Hoegh-Guldberg, O., Hoegh-Guldberg, H., Veron, J.E.N., Gree, A., Gomez, E. D., Lough, J., King, M., Ambariyanto, Hansen, L., Cinner, J., Dews, G., Russ, G., Schuttenberg, H.Z., Penaflor, E.L., Eakin, C.M., Christensen, T.R.L., Abbey, M., Areki, F., Kosaka, R. A., Tewfik, A., and Oliver, J. 2009. The Coral Triangle and Climate Change: Ecosystems, People and Societies at Risk. WWF Australia, Brisbane, Australia.

Indrawan, M. and Suseno. 2008. The complications of CITES inclusion of endemic species in Indonesia: Lessons learned from an in-country deliberation on protecting the Banggai cardinalfish, Pterapogon kauderni. SPC Live Reef Fish Information Bulletin \#18:13-16

Jompa, J. 2009. Coral Triangle Initiative ( CTI ) on Coral Reefs, Fisheries and Food Security. Presentation at the Sosialisasi Rencana CTI Nasional in Palu, June 2009.

Kolm, N., Hoffman, E.A., Olsson, J., Berglund, A., and Jones, A.G. 2005. Group stability and homing behavior but no kin group structures in a coral reef fish. Behavioral Ecology 16:521-527

Koumans, F.P. 1933. On a new genus and species of Apogonidae. Zoologische Mededeelingen (Leiden) 16 (1-2): 78, PI. 1.

Latupono, F. 2008. Laporan Evaluasi Enumerator BCF Tahun 2008. Presentation at the "Apresiasi Pengelolaan dan Pemanfaatan Banggai Cardinalfish", 23-25 November 2008 in Palu.

Latupono, F. 2009. Data Enumerator BCF Tahun 2009.

Lilley, R. 2008. The Banggai cardinalfish: An overview of conservation challenges. SPC Live Reef Fish Information Bulletin \#18:3-12

LP3L Talinti. 2006. Pendataan Habitat, Populasi dan Pemanfaatan Ikan Hias di Pulau Banggai, Sulawesi Tengah sebagai Dasar Perencanaan Pemanfaatan Bekelanjutan Secara Ekologis dan Ekonomis. Laporan Akhir pada Progam Mitra Bahari (RC Sulawesi Tengah), Palu, Indonesia.

Lunn, K.E. and Moreau, A.M. 2001. Conservation of Banggai Cardinalfish Populations in Sulawesi, Indonesia, an Integrated Research and Education Project, Zoological Society of London, London, UK. (unpublished report)

Lunn, K.E. and Moreau, A.M. 2004. Unmonitored trade in Marine Ornamental Fishes: the Case of Indonesia's Banggai Cardinalfish (Pterapogon kauderni). Coral Reefs (2004) 23:344-341.

Moore, A. and Ndobe, S. 2009. Reefs at risk in Central Sulawesi, Indonesia - status and outlook. Proceedings of the 11th International Coral Reef Symposium, Ft. Lauderdale, Florida, 7-11 July 2008. Session number 18. pp. $840-844$

Moore, A. and Ndobe, S. 2007a. The Banggai Cardinalfish and CITES - a local perspective. Reef Encounters Vol.38:15-17.

Moore, A. and Ndobe, S. 2007b. Discovery of an introduced Banggai Cardinalfish population in Palu Bay, Central Sulawesi, Indonesia. Coral Reefs 26:569. 
Moore, A. and Ndobe, S. 2010a. Conservation of Small Island Endemic Species - Banggai Cardinalfish Case Study. Paper presented at the International Symposium on Small Islands and Coral Reefs (ISSIC) in Ambon, 4-5 August 2010. In press.

Moore, A. and Ndobe, S. 2010b. The Banggai cardinalfish: an overview of management and conservation initiatives. Paper presented at the 2nd Asia Pacific Coral Reef Symposium Collaboration for Coral Reef Conservation in a Changing Climate, 20-24 June 2010, Phuket, Thailand. In press

Ndobe, S. and Moore, A. 2009. Banggai cardinalfish: towards a sustainable ornamental fishery. Proceedings of the 11th International Coral Reef Symposium, Ft. Lauderdale, Florida, 7-11 July 2008 pp.10261029

Ndobe, S., Moore, A., Nasmia, Madinawati, and Serdiati, N. 2010a. The Banggai cardinalfish: an overview of local research (2007-2009). Paper presented at the 2nd Asia Pacific Coral Reef Symposium, Collaboration for Coral Reef Conservation in a Changing Climate, 20 - 24 June 2010, Phuket, Thailand

Ndobe, S., Madinawati, and Moore, A. 2008. Pengkajian Ontogenetic Shift pada Ikan Endemik Pterapogon kauderni. Jurnal Mitra Bahari. Vol. 2 No.2: 32-55

Ndobe, S., Moore, A., and Supu, A. 2005. Sulawesi Case Study - Banggai Kepulauan. Pages 5-143 \& 165-229 in The Indonesian Ornamental Fish Trade: Case Studies and Options for Improving Livelihoods while Promoting Sustainability in Banggai and Banyuwangi. The International Seafood Trade: Supporting Sustainable Livelihoods Among Poor Aquatic Resource Users in Asia (EC Prep Project EP/RO3/R14). Poseidon and Network of Aquaculture Centres in Asia (NACA) STREAM.

Ndobe, S., Moore, A., and Ederyan. 2010b. Perkembangan IPTEK dan Pengelolaan Ikan Endemik Banggai Cardinalfish 2007-2010 Developments in Science and Management of the Endemic Banggai Cardinalfish 20072010. Paper presented at the Simposium Nasional Pembangunan Kelautan dan Perikanan Kawasan Timur Indonesia, 1-2 August 2010 in Ambon. In press.

Ndobe, S., Moore, A., Ederyan, and Salanggon, A.I.M. 2006a. Bioekologi dan Konservasi Ikan Endemik Banggai Cardinalfish Pterapogon kauderni. Dinas Kelautan dan Perikanan Propinsi Sulawesi Tengah kerjasama dengan Lembaga Penelitian dan Pengabdian pada Masyarakat (LP3M STPLPalu), Palu.

Ndobe, S., Moore, A., Supu, A., and Ederyan. 2006b. Status dan Prospek Pemanfaatan Endemik Banggai Cardinalfish di Kepulauan Banggai. Dinas Kelautan dan Perikanan Propinsi Sulawesi Tengah kerjasama dengan Lembaga Penelitian dan Pengabdian pada Masyarakat (LP3M STPL-Palu), Palu.

Saputra, E.J. 2010. Strategi Pengembangan Agribisnis Ikan Hias Laut Pulau Banggai di Kabupaten Banggai Kepulauan Agribusiness Development Strategy For Marine Ornamental Fish In Banggai Island, Banggai Kepulauan District. Thesis submitted for a Masters Degree in Agribusiness at Tadulako Unuversity, Palu

Vagelli, A. 2004. Ontogenetic Shift in Habitat Preference by Pterapogon kauderni, a Shallow Water Coral Reef Apogonid with Direct Development. Copeia 2004(2) 364369.

Vagelli, A.A. and Erdmann, M.V. 2002. First Comprehensive Survey of the Banggai Cardinalfish, Pterapogon kauderni. Environmental Biology of Fishes 63:1-8

Vagelli, A.A. 2005. Reproductive Biology, Geographic Distribution and Ecology of the Banggai Cardinalfish Pterapogon kauderni Koumans, 1933 (Perciformes, Apogonidae), with Considerations on the Conservation Status of this Species on its Natural Habitat. $\mathrm{PhD}$. Dissertation, University of Buenos Aires, Argentina.

Vagelli, A.A. 2008. The unfortunate journey of Pterapogon kauderni: A remarkable apogonid endangered by the international ornamental fish trade, and its case in CITES. SPC Live Reef Fish Information Bulletin \#18:17-28

Vagelli, A.A., Burford, M., and Bernardi, G. 2009. Fine scale dispersal in Banggai Cardinalfish, Pterapogon kauderni, a coral reef species lacking a pelagic larval phase. Marine Genomics 1:129-134. 